\title{
Judgment on Hadiths According to Imam Daoudi
}

Mwadah Ibrahim Alfaadhli, Mohamed Fathy Mohamed Abdelgelil, Ahmad Fauzi Hassan, Reda Owis Hassan Serour, Mohd Shaifulbahri Abdullah, Rosmalizawati Abd. Rashid

To Link this Article: http://dx.doi.org/10.6007/IJARBSS/v11-i9/11184

DOI:10.6007/IJARBSS/v11-i9/11184

Received: 11 July 2021, Revised: 09 August 2021, Accepted: 30 August 2021

Published Online: 21 September 2021

In-Text Citation: (Alfaadhli et al., 2021)

To Cite this Article: Alfaadhli, M. I., Abdelgelil, M. F. M., Hassan, A. F., Serour, R. O. H., Abdullah, M. S., \& Rashid, R. A. (2021). Judgment on Hadiths According to Imam Daoudi. International Journal of Academic Research in Business and Social Sciences, 11(9), 1481-1488.

\section{Copyright: (c) 2021 The Author(s)}

Published by Human Resource Management Academic Research Society (www.hrmars.com)

This article is published under the Creative Commons Attribution (CC BY 4.0) license. Anyone may reproduce, distribute, translate and create derivative works of this article (for both commercial and non-commercial purposes), subject to full attribution to the original publication and authors. The full terms of this license may be seen at: http://creativecommons.org/licences/by/4.0/legalcode

\section{Vol. 11, No. 9, 2021, Pg. 1481 - 1488}

Full Terms \& Conditions of access and use can be found at http://hrmars.com/index.php/pages/detail/publication-ethics 


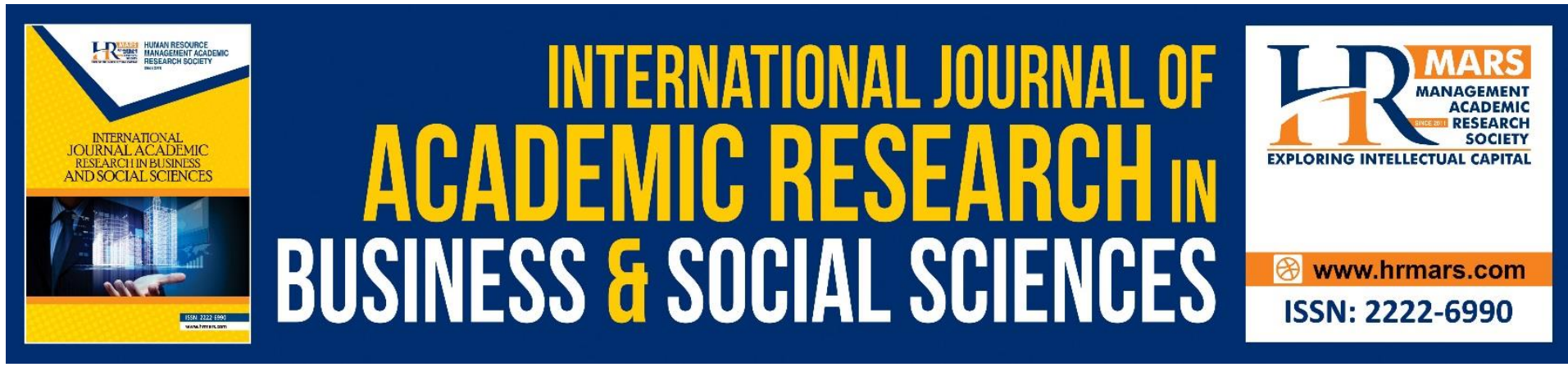

\title{
Judgment on Hadiths According to Imam Daoudi
}

\author{
${ }^{1}$ Mwadah Ibrahim Alfaadhli, ${ }^{1}$ Mohamed Fathy Mohamed \\ Abdelgelil, ${ }^{1}$ Ahmad Fauzi Hassan, ${ }^{2}$ Reda Owis Hassan Serour, \\ ${ }^{1}$ Mohd Shaifulbahri Abdullah, ${ }^{1}$ Rosmalizawati Abd. Rashid \\ ${ }^{1}$ Faculty of Islamic Contemporary Studies (FKI), Sultan Zainal Abidin University (UniSZA), \\ 21300, Terengganu, MALAYSIA, ${ }^{2}$ Sultan Abdul Halim Mu'adzam Shah International Islamic \\ University, (UniSHAMS), Malaysia. \\ Email: mfathy@unisza.edu.my
}

\begin{abstract}
Tripoli, west of Libya, embraced many imams of hadith, including Imam Ahmed bin Nasr AlDaoudi. He was born in Algeria and then moved to Tripoli in the West, where he settled and spread knowledge, during the days of the state of the plight of Bani Ubaid in Almaghrib, who were the cause of the deterioration of political, social and scientific life. Where their history was famous for injustice, insulting the Companions and killing alaulamah, until innovations and evils appeared in their state, and the people of corruption increased and the righteous among them were few among the alaulamah and servants. The one who is interested in the science of hadith must know the efforts of al-Dawudi in hadith, due to his position and progress in this art. The one who is interested in the science of hadith must know the efforts of al-Dawudi in hadith, due to his position and progress in this art. He can only do that after a lot of trouble, because of the loss of most of his precious books and classifications. The research aims to know the efforts of Daoudi in judging hadiths, and to clarify what is accepted from them and what is not. Moreover, one of the results of the research is that Al-Daoudi is an imam in criticizing the narrators; He was not just a transmitter of the rulings of others, rather he had a prominent effect in correcting hadiths, criticism and explaining the reasons, so he used several words in jarh and ta'deel, and heopted some of the words that indicate acceptance, such as his saying: it is proven, or the established, and his saying: it is not correct, and in its chain of transmission a look at the hadith in which there is fault, and his saying: In the chain of transmission of the hadith there is an article, and this is for the chain of transmission that the scholars differed regarding the authentication of one of its men. AlDawudi confined himself to the least that would achieve the purpose, and he did not go beyond that to anything above it.
\end{abstract}

Keywords: Hadiths, Imam Daoudi, According, Judgment.

\section{Introduction}

Praise be to Allah, Lord of the Worlds, and the outcome for the righteous, and prayers and peace be upon our master Muhammad peace be upon him and his family and companions, and may peace and blessings be upon the Day of Judgment. 
When delusion and error occurred in the novel; Rather, the lie appeared to the Prophet, may Allah bless him and grant him peace, at that time, Allah subjugated a group of memorized imams, they worked hard in collecting antiquities, and the fourth century AH did not end until their works had absorbed the hadiths of the Messenger of Allah, may Allah bless him and grant him peace, and the traces of his companions. The books of al-Jarh and al-Ta'deel and an explanation of the conditions of narrators were also compiled, to distinguish the correct from the weak and the right from the disease. The imams took several approaches to reach their goal. Knowing the approach of the forerunners was a must, because the people of knowledge are not on a single approach in the alhadithia industry; Rather, it is based on multiple approaches, so it is necessary to know their method and then follow it.

Imam Ahmad Al-Daoudi was one of these imams; He is one of those who took care of him, so they distinguished between the true and the weak hadith, so Al-Dawudi was one of the people of experience and insightful understanding, and when Daoudi's efforts in serving the Sunnah were of such great importance, it was worth directing the efforts of alaulamah and researchers to him, translating his life, and extracting his ideas, opinions and judgments.

\section{Background}

In order to know the topic around which the research revolves, a brief explanation of the introduction to Imam Ahmed Al-Daoudi and the study of his era must be provided, Imam Daoudi lived during the era of the state of Bani Ubaid, which was established in the year 297 $\mathrm{AH}$ in the Arab Maghreb, and its founder is Ubaid who entered the country of the Maghreb and was called Ubaid Allah, and he was a Jew, and he told Judge Ayyad that the Sunnis in Kairouan were in the days of Bani Ubaid, in a severe state of Seizing and covering up, as if they were a dhimma, severe ordeals overwhelmed them during many days (Ayad, D. T., 5:303). Naji said: Their era in Tripoli was one of chaos and calamities. (Naji, 1970, pg. 136).

\section{Introducing Imam Ahmad Daoudi}

He is Ahmed bin Nasr Al-Daoudi, Al-Asadi, Al-Musili by birth, Al-Trabelsi by birth, Al-Tilmisani by death. (lyad, 1982, 7: 102-104, and Al-Zawi, 2004, p. 92).

Imam Daoudi left his hometown, Msila, to Tripoli. His first life was in Tripoli, the West, where he resided there and sought knowledge there. He dictated his developing book in Sharh AlMuwatta. In pursuit of knowledge, he moved to Tlemcen and settled there until his death in 402 AH (Ayad, 1982, 7: 102-104, and Al-Zawi, 2004, p. 92).

\section{Judgment on hadiths according to Imam Daoudi}

As al-Dawudi was one of the imams of the muhaddithin auolamah, so he made efforts to judge the hadiths and to clarify what is acceptable from the rejected.

\section{Daoudi Correction of Hadiths}

Al-Bukhari included in the Book of Fasting, chapter of the one who dies owing fasting, with his chain of transmission on the authority of Ibn Abbas, may Allah be pleased with him, who said: A man came to the Prophet, may Allah bless him and grant him peace, and said: $O$ Messenger of Allah, my mother died and she had to fast for a month, shall I make it up to her? He said: "Yes..."

Then Al-Bukhari mentioned another chain of transmission on the authority of Ibn Abbas: A woman said to the Prophet, may Allah's prayers and peace be upon him: My sister died... 
And it was also narrated with another chain of narrators: "On the authority of Ibn Abbas: A woman said to the Prophet, may Allah's prayers and peace be upon him: My mother died and she owed a vow and fast..." (Bukhari 3:35, 2002).

Ibn al-Mulqen said: "In the hadith: (Indeed, my mother is obligated to fast for a month), and in the other: (a vow fasting), and in another: (My sister). And it is not a disturbance other than the words of Abdu al-Malik: It is a great disorder that indicates the illusion of the narrators, and without it, the hadith is elevated" (Ibn Al-Mulqen, 2008, 13: 387, 388).

Then Ibn al-Mulqen said: "Al-Daoudi was right and said: This is not something that weakens him, and it may be that all of them asked him, and he narrated at times from some of them, and at times from others he said: Perhaps Malik did not reach him with this hadith, or he weakened it due to the disagreement in its chain of transmission (Ibn Al-Mulqen, 2008, 13: 388).

\section{His saying: (It does not prove)}

Al-Daoudi said: Ibn Idris - referring to Imam al-Shafi'i - argued with a hadith that is not proven in transmission: that the Prophet gave Banu Hashim and Banu al-Muttalib from one-fifth of the khums, so Othman and Jubayr bin Mut'im walked to him and said: O Messenger of Allah, you have given Bani Al-Muttalib, and we and they are equal to you? He said: Banu Hashim and Banu al-Muttalib are one and the same, and he intertwined his fingers. (Al-Daoudi, 2008, p. 37).

The hadith that al-Dawudi mentioned was included by Abu Ubaid in al-Mawwal, Book of the Khums and its Rulings and Sunnahs, chapter on the share of relatives of the five. (Abu Obeid, N. D., 1: 456, No. 833).

Then Al-Daoudi said: "And what is proven in the narration is that he gave Banu Hashim and Banu al-Muttalib from the five, and there is no mention of the fifth of the fifth, and he had a share in the five, so he gave them from it, so he settled between them and Hashem, and from him he gave the author their hearts on the day of Hunayn" (Al-Dawudi, 2008, p. 37).

\section{His saying: (in its chain of narration)}

Al-Dawudi used this word in many places, and it appears that he uses it for the hadith in which the chain of transmission is interrupted, and from these places:

1- directed by Bukhari in the book albuyua, the door of the interpretation of alearaya, Bssande "Ibn Umar, Zaid ibn Thabit, may Allah be pleased with him: « that the Messenger of Allah peace be upon him licenses alearaya to be sold Boukrsa agent "Musa bin said obstacle and alearaya: palms of information you come to buy it" (Al-Bukhari, 2002, 3: 76, No. 2192). Ibn al-Mulqen said: "Al-Daoudi said: It was narrated with a chain of narrators in which there is consideration: That he, peace and blessings of Allah be upon him, gave permission to sell the aleariat Before it becomes good, its goodness is made of dates" (Ibn Al-Mulqen, 2008, 14: 477).

Ibn al-Mulqen intended as directed by Shafei commenting in the book albuyua, chapter selling alearaya, he said: "Mahmoud Ben Lapid said a man from the companions of the Prophet peace be upon him-either Zaid ibn Thabit either Gerh- what these Arayakm? So and so said so and so " (Shafi'i, 1990, 3:54).

"Mahmoud bin Labid said to a man from the companions of the Prophet, may Allah bless him and grant him peace - either Zaid bin Thabit or someone else - What your earayakum these? So and so said..." (Al-Shafi'i, 1990, 3:54). 
And Ibn Abdul-Barr mentioned it in "Al-Tamheed" and said: Its chain of transmission is interrupted (Ibn Abdul-Barr, $1387 \mathrm{AH}, 2$ : 330). Al-Zayla'i said in the installation of the banner in response to those who said that this hadith is agreed upon: "This is not in the two Sahihs, nor in the Sunan; rather, nor in any of the well-known books, and I did not find a chain of narrators for it after extensive examination, but Al-Shafi'i mentioned it in his book in Bab AlAraya without a chain of transmission" (Al-Zayla'i, 1997, 4:14).

2- Al-Daoudi said: "It was narrated from a path in its chain of narrators that it was seen that it was the nafl of Ibn Masoud Saif Abu Jahl, and he was the one who cut off his head" (AlDawdi, 2008, pg. 30).

The hadith was included by Abu Dawood in his Sunan, The Book of Jihad, Chapter: Who Permitted a Wounded Person, he said: Harun bin Abbad Al-Azdi told us, Waki' told us, on the authority of his father, on the authority of Abu Ishaq, on the authority of Abu Ubaidah, on the authority of Abdullah bin Masoud, he said: The Messenger of Allah, may Allah bless him and grant him peace, given me on the day of Badr, the sword of Abu Jahl, he was killed" (Abu Dawood, 2009). 4: 356, No. 2722).

And Daoudi's saying: (It was narrated from a path in its chain of narrators) refers to the reason for the interruption in the chain of transmission, which is that Abu Ubaidah did not hear from his father Abdullah bin Masoud.

Al-Daraqutni was asked about hearing Abu Ubaidah bin Abdullah bin Masoud, on the authority of his father, is it true? He said about the ills: "There is a difference of opinion about it, and the correct one is that he did not hear from him, but he was young in his hands" (AlDaraqutni, $1405 \mathrm{AH}$, 5:308).

Abu Hatim denied hearing Abu Ubaidah from his father explicitly; When he was asked about his hearing from his father, he said: "He did not hear" (Ibn Abi Hatim, 1397 AH, p. 256).

\section{His saying: (in the hadith is an Maqal)}

Al-Daoudi used this word in several places, referring to weakness, including:

Al-Daoudi said: "Ismail said, and Muhammad bin Abdul-Malik told us, he said: Abu Salih told us, he said: I am Al-Layth bin Saad, on the authority of Aqeel, on the authority of Ibn Shihab, on the authority of Salem, on the authority of his father: "The Messenger of God, may Allah bless him and grant him peace, He was ynaffel to those who were sent from the palaces to themselves Alnafel. except for the general oath of the army. He said: And one-fifth of that is obligatory (Al-Daoudi, 2008, p. 21).

And Muslim in the Book of Jihad and Alssiar, the chapter of the Anfal, said: "Tell us Abdul Malik bin Shuaib bin Laith, told me my father, from my grandfather, he said, told me Aqeel bin Khalid ..." (Bukhari, 2002, 4: 90, No. 3135; Muslim, N. D., 3: 1369, No. 1750).

Al-Daoudi said: "In the hadith is an Maqal, and if it was proven, he would not have an argument for it, because Ibn Omar did not attend every group, so he testifies to all" (Al-Dawdi, 2008, p. 21).

What is meant by Daoudi's saying (in the chain of hadith is an Maqal) refers to Abu Salih, who is Abdullah bin Saleh bin Muhammad bin Muslim Al-Juhani Abu Salih Al-Masri, the writer of Al-Layth bin Saad. Imam and others, and it was narrated by Abu Dawood, Al-Tirmidhi and Ibn Majah through Al-Hasan bin Ali Al-Khalal, Abu Hatim Al-Razi, and Yahya bin Ma'in, he died in the year $222 \mathrm{AH}$. (Ibn Uday, 1997, 5: 342-347; Al-Mazi, 1980, 15: 98-109). 


\section{His Saying: (It is not correct)}

Al-Daoudi used this word in many places, and it is more severe in his opinion than his saying: There is an Maqal in it, or with a weak chain of narrators.

Directed by Bukhari in the book of alddaeawat, Bssande "for Qatada, he said: I heard ANSA said: Um Salim told to the Prophet: Anas your servant, said: " O Allah, increase his wealth and his children, and bless him with what you have given him »" (Bukhari, 2002, 8: 73, No. 6334). Ibn al-Mulqen said in his explanation of this hadith: "Al-Daoudi said: It was narrated from a path that is not proven: "O Allah, whoever believes in me and believes what I have come, then give him less money and children." He said: This is not correct, how can the legislator encourage marriage and seek a child" (Ibn al-Mulqen, 2008, 29: 248).

The hadith that al-Dawudi mentioned in the form of altamrid and ruling that it was not proven, was included by Ibn Majah in the Book of Al-Zuhd, chapter on the multitudes, with its chain of transmission on the authority of Amr bin Ghailan Al-Thaqafi. (Ibn Majah, Dr. T. 2:1385, No. 4133).

Al-Busiri said: "Amr bin Ghaylan has nothing with Ibn Majah except this hadith, and he has no narration in any of the five books, and he differs in his companionship" (Al-Busiri, $1403 \mathrm{AH}, 4$ : 221, 222). And Abu Hatim al-Razi said about him: "Weak hadith, munkar hadith" (Ibn Abi Hatim, 1952, 6: 267). Ibn Abd al-Barr said: "His hadith according to the people of Syria is not strong" (Ibn Abd al-Bar, 1992, 3: 1197).

The study indicates that what is meant by Daoudi's saying: (It is not correct in transmission); Meaning: The companions of the Sahih did not see it, and only Ibn Majah saw it. And his saying: (Not in consideration); i.e.: It is not suitable for weighting with what was proven on the authority of Anas, which Al-Bukhari previously reported, so it is not considered a followup or witness. It is clear from this study that Al-Dawudi judges the hadith that has a defect in the chain of transmission and a defective defect in the text by saying: (It is not authentic).

\section{Conclusion}

At the end of this research, the most important findings can be shown as follows:

- Al-Dawudi is an imam in criticism of narrators. So he used several words in the wound and the modification, and his independence in some of them, such as: His saying: (proven, or established) is evidence of correctness. And his saying: (It is not correct) for the hadith that has a defect in the chain of transmission and a defective defect in the text, which in his view is more severe. And his saying (in its chain of transmission is a review) of the hadith in which its chain of transmission is interrupted. And his saying: (It does not prove), and his saying: (In the chain of transmission of the hadith is an Maqal), Referring to the chain of transmission that scholars differed in documenting one of his men's injuries and modifications.

He also rejects the hadith if its apparent contradiction with what is known from the religion by necessity, and it appears that it is limited to the least that achieves the purpose and does not go beyond that to what is above it.

\section{References}

Al-Quran Al-Karim.

Abdelgelil, M. F. M. (2020). Grammarians' Critique of Qur'anic Qira'at. International Journal of Academic Research in Business and Social Sciences, 10(11), 1225-1231.

Abdelgelil, M. F. M. (2020). Solving the Quranic Issues with Quranic Qira'at, International Journal of Academic Research in Business and Social Sciences, 10(12), 36-42. 
Abdelgelil, M. F. M., Al-Janayni, M. U., Baru, R., Hamzah, M. S., Razali, M. A. T. M., \& Ismail, F. Z. (2018). Tawjih Al-Qira'at Based on Inscription, Language, and Unusual Modes of Recitation According to Ibn Zanjalah. International Journal of Academic Research in Business and Social Sciences, 8(10), 362-370.

Abdelgelil, M. F. M., Daud, N. B., Omar, N. B., Ismail, F. Z. B., \& Wahab, A. H. B. A. (2018). Taujeeh Al-Qira'at Using Qur'an, Hadith and Poetry according to Ibn Zanjalah. International Journal of Academic Research in Business and Social Sciences, 8(10), 371379.

Abdelgelil, M. F. M., Hasan, A. F., Yusoh, F, El khayat, M. H. M., Razali, M. A., Ismail, F. Z., \& Ab Rashid, R. (2021). Correlation Between Irregular Qiraat And Arabic Linguistics In The Quranic Tafseer Book By Al-Razi. International Journal of Academic Research in Business and Social Sciences, 11(7), 1632-1639.

Abdelgelil, M. F. M., Hasan, A. F., Yusoh, F., Ismail, F. Z., Ab Rashid, R., Ab Aziz, N. S., Hassan, A (2021). The Impact of Irregular Qiraat on Arabic Semantics and Dialects. International Journal of Academic Research in Business and Social Sciences, 11(7), 1672-1676.

Abdelgelil, M. F. M., Hasan. A. F., Yusoh, F., El khayat, M. H. M., Razali, M. A., Hassan, A., Ab Aziz, N. S. (2021). Arabic Syntactic Rules with Reference to Quranic Qurra. International Journal of Academic Research in Business and Social Sciences, 11(7), 1707-1711.

Abdelgelil, M. F. M., Musolin, M. H., Serour, R. O. H., Abdullah, M. S., \& Noor, M. N. M. (2018). Law and Moral Values in the Holy Quran. International Journal of Academic Research in Business and Social Sciences, 8(11), 445-451.

Abdelgelil, M. F. M., Osman, M. F. M. A., Serour, R. O. H., Subagio, M. H. M., Othman, A. K. I., \& Hassan, A. F. (2021). The History of the Qur'anic Enigma and the Impact of Interpretation in Directing it. International Journal of Academic Research in Progressive Education and Development, 10(3), 412-418.

Abdelgelil, M. F. M., Othman, A. K. I., Serour, R. O. H., Osman, M. F. M. A., \& Hassan, A. F. (2021). Ibn Qutayba's Response to the Slanderers who Claim Grammatical Mistake in the Qur'an. International Journal of Academic Research in Progressive Education and Development, 10(3), 419-426.

Abdelgelil, M. F. M., Othman, A. K. I., Subagio, M. H. M., Serour, R. O. H., Hassan, A. F., \& Osman, M. F. M. A. (2021). Directing the Enigma of Quranic Words According to Ibn Qutaybah and Al-Far. International Journal of Academic Research in Progressive Education and Development, 10(3), 427-434.

Abdelgelil, M. F. M., Hassan, A., Yusof, N. H., Idris, M. F. H., Hasan, A. F., \& Ramadan, A. A. (2020). Defending the Quran in the Study of Tawjeeh Al-Qira'at, International Journal of Management, 11(10), pp. 101-104.

Abdelgelil, M. F. M., Razali, M. A., Hassan, A., Hasan, A. F., Idris, M. F. H., \& Masoud. (2020). A.S,Quranic Inimitability in Quranic Qiraat, International Journal of Management, 11(10), pp. 117-121.

Abu Dawud, S. (2009). Sunan Abi Dawood. Investigated by: Shuaib Al-Arnaout, and Muhammad Kamel Qara Belli. Global Message House.

Abu Obeid, Q. (N. D). Alamwal book. Investigation: Khalil Haras. Beirut: Dar Al-Fikr.

Al-Bukhari, M. (2002). Sahih Bukhari. Investigation: Muhammad Zuhair Al-Nasser. Beirut: Lifeline House.

Al-Busiri, A. (1403AH). misbah alzujajat fi zawayid Ibn Majah. Investigated by: Muhammad AlMuntaqa. Beirut: Dar Al Arabiya. 
Al-Daraqutni, A. (1985). The ills mentioned in the hadiths of the Prophet. Investigation: Mahfouz Al-Rahman Zain Allah Al-Salafi. Riyadh: Dar Taiba.

Al-Mazi, Y. (1980). Refinement of perfection in men's names. Investigation: Bashar Awad Maarouf. Beirut: Al-Resala Foundation.

Al-Shafi'i, M. (1990). Alumm. Beirut: House of Knowledge.

Al-Zawi, A. (2004). Aalam of Libya. Beirut: Dar al-Madar al-Islami, Tripoli: Dar Oya.

Al-Zaylai, A. (1997). Setting up the Alrrayah for the hadiths of guidance. Investigation: Muhammad Awamah. Saudi Arabia: House of Qibla for Islamic Culture. Beirut: Al Rayan Foundation.

Daoudi, A. (2008). Alamwal book. Investigation: Reda Muhammad Salem Shehadeh. Beirut: Scientific Books House.

Ibn Abd al-Bar, Y. (1387AH). The prelude to what is in Al-Muwatta of meanings and chains of transmission. Investigation: Mustafa Ahmed Al-Alawi and Muhammad Abdul-Kabir. Morocco: Ministry of Awqaf.

Ibn Abd al-Bar, Y. (1992). Accommodation in knowing al'ashab. Investigation: Ali Muhammad Al-Bajawi. Beirut: House of Generation.

Ibn Abi Hatim, A. (1952). aljurh waltaedil. India: Ottoman Encyclopedia, Beirut: Arab Heritage Revival House.

Ibn al-Mulqen, S. (2008). Illustration to explain the correct whole. Investigation: Dar Al-Falah, Damascus: Dar Al-Nawader.

Ibn Majah, M. (N. D). Sunan Ibn Majah. Investigation: Mohamed Fouad Abdel Baqi. Beirut: House of Revival of Arabic Books.

Ibn Uday, J. (1997). full in weak men. Investigation:el Ahmed Abdel Mawgod and Ali Mohamed Moawad. Beirut: Scientific Books House.

Iyadh, A. (1982). Tartib Almadarik Wataqrib Almasalik. Investigation: Saeed Ahmed Arab. Morocco: Ministry of Endowments and Islamic Affairs.

lyadh, A. (N. D). Tartib Almadarik Wataqrib Almasalik. Investigation: Muhammad bin Sharifa. Morocco: Ministry of Endowments and Islamic Affairs.

Muslim, I. (N. D). Sahih Muslim. Investigation: Muhammad Abdul Baqi. Beirut: Arab Heritage Revival House.

Nagy, M. (1970). History of Tripoli West. See: Abdel Salamham. Benghazi: Libyan University Publications. 